\title{
Influence of soda-lime waste glass microparticles on workability and thermal properties of portland cement compounds
}

\author{
C. B. C. S. Alvarenga ${ }^{a}$, O. M. Heiderick ${ }^{\mathrm{a}}$, T. A. Couto ${ }^{\mathrm{b}}$, P. R. Cetlin ${ }^{\mathrm{a}}$, \\ R. B. C. Sales $₫$, M. T. P. Aguilar ${ }^{\mathrm{a}}$ \\ a. Universidade Federal de Minas Gerais, Escola de Engenharia (DEE, DEMC, DEMEC) Belo Horizonte (Minas Gerais, Brasil) \\ b. Cimentos Brennand, Laboratório de Análises, Sete Lagoas, (Minas Gerais, Brasil) \\ c. Universidade do Estado de Minas Gerais, Escola de Design (DEPC), Belo Horizonte (Minas Gerais, Brasil) \\ $\triangle$ rosemary.sales@uemg.br
}

\begin{abstract}
Numerous studies have investigated the use of waste glass as a partial substitution in Portland cement. Nonetheless, it seems there is no consensus about the influence of particle size and color on the behavior of the compounds. This work investigates the influence of soda-lime glass microparticles on the properties of cement and mortar in both fresh and hardened states. The effects of partial substitution (10 and 20\%) of the cement by colorless and amber glass particles with dimensions of approximately $9.5 \mathrm{~mm}$ were investigated. The results revealed that the substitutions did not significantly affect the setting times, nor the mechanical properties of mortar at longer curing times. The influence of glass content and chemical composition on workability and hydration heat was also observed. The waste glass samples showed lower thermal diffusivity than the control sample. Thermal emissivity was not influenced by the presence of glass microparticles.
\end{abstract}

KEYWORDS: Portland cement; Glass; Mortar; Fresh concrete; Mechanical properties; Transport properties.

Citation/Citar como: Alvarenga, C. B. C. S.; Heiderick, O.M.; Couto, T.A.; Cetlin, P.R.; Sales, R.B.C.; Aguilar, M.T.P. (2019) Influence of soda-lime waste glass microparticles on workability and thermal properties of portland cement compounds. Mater. Construcc. 69 [335], e192 https://doi.org/10.3989/mc.2019.05818

RESUMEN: Iinfluencia de micropartículas de residuos de vidrio soda-lime en la trabajabilidad y propiedades térmicas de compuestos de cemento portland. Diferentes estudios han investigado el uso de residuos de vidrio como un sustituto parcial del cemento Portland. Sin embargo, parece no haber consenso sobre la influencia del tamaño o del color de la partícula en el comportamiento de los compuestos. Este trabajo aborda la influencia de micropartículas de vidrio soda-lime en las propiedades del cemento y de los morteros tanto en estado fresco como endurecido. Se han investigado los efectos de la sustitución parcial del 10 y $20 \%$ del cemento por partículas de vidrio incoloro o color ámbar con dimensiones alrededor de $9.5 \mathrm{~mm}$. Los resultados revelaron que las sustituciones no afectan notablemente los tiempos de fraguado, tampoco las propiedades mecánicas de los morteros en los tiempos más largos de curado. Se observó la influencia del contenido y composición química del vidrio en la trabajabilidad y calor de hidratación. Las muestras con residuos vítreos mostraron una difusividad térmica más baja que la muestra sin residuos. La emisividad termica no se vió afectada por la presencia de micropartículas de vidrio.

PALABRAS-CLAVE: Cemento Portland; Vidrio; Mortero; Hormigón fresco; Propiedades mecánicas; Propiedades de transporte.

ORCID ID: C. B. C. S. Alvarenga (https://orcid.org/0000-0002-5309-2020); O. M. Heiderick (https://orcid.org/00000002-5001-1010); T. A. Couto (https://orcid.org/0000-0003-4139-5849); P. R. Cetlin (https://orcid.org/0000-0002-8051062X); R. B. C. Sales (https://orcid.org/0000-0002-9475-0835); M. T. P. Aguilar (https://orcid.org/0000-0002-0121-0881)

Copyright: (C) 2019 CSIC. This is an open-access article distributed under the terms of the Creative Commons Attribution 4.0 International (CC BY 4.0) License. 


\section{INTRODUCTION}

The nominal capacity of flat glass production in Brazil is 6,680 tons / day and is associated with an annual income of US\$1 billion (1). Waste from glass production accounts for an average of 3\% of all urban waste. Of this, 99\% results from damage during manufacture (treatment, drilling, cutting, and handling) of glass parts. Less than $50 \%$ of this waste is recycled; the rest is disposed of directly in landfills (2). The glass waste can be used in the remanufacture of glass in case that it is in the form of cullet because they are inert and not biodegradable. However, glass microparticles from polishing and drilling are an environmental liability because their recycling is not economically feasible.

Considering that glasses are non-crystalline ceramic materials whose chemical composition is high in amorphous silica, several studies point to the possibility of using waste glass in the preparation of alternative binders, such as alkali-activated materials and geopolymers (3-5). According to the literature, waste glass can also be used as sand, gravel, or supplementary cementitious material in eco-efficient concretes. The use of waste glass is an alternative that mitigates negative impacts related to Portland cement production, such as high energy consumption, greenhouse gas emission, and natural resource consumption (6-11).

The use of glass in Portland cement composites requires special care, since the alkali-silica reaction may occur and cause cracks in the cementitious compounds $(12,13)$. However, depending on the particle size, the glass may instead exhibit pozzolanic activity and thus inhibit the alkali-aggregate reaction (14-16). Some studies investigated the effect of glass microparticles on the properties of Portland cement composites and indicated that glass did not affect the setting time, soundness, and flexural strength of the material $(15,17,18)$; however, it did have a negative effect on the workability $(15,19)$. Few studies cover the hydration heat and elastic modulus of glasscontaining cements $(17,19)$, and there are conflicting results on the effect of glass on the compression strength of the material $(16,18-21)$. Additionally, studies show inconclusive results as to the influence of glass color on the properties of compounds in both fresh and hardened states $(15,17,21,22)$.
Regarding the use of glass particles, data on the actual performance of concretes made with glass aggregates and subjected to high temperatures are available (1). However, no studies on the thermal properties of structural cementitious compounds made with glass microparticles have been found.

This work addresses how the substitution of 10 and $20 \%$ of cement by colorless and amber sodalime glass microparticles affects the properties of cement and mortar in both fresh and hardened states. The analysis is based on setting time, calorimetry, soundness, workability, compressive strength, flexural strength, and elastic modulus properties; and thermographic tests. The objective of the present research is to verify the results in the literature and clarify the influence of glass microparticles on the hydration heat, elastic modulus, compression strength, and thermal properties of cement. The influence of the glass chemical compositions on the performance of the cementitious composites is also examined.

\section{MATERIALS AND METHODS}

Colorless and amber soda-lime waste glass microparticles were prepared in laboratory conditions to prevent contamination. The chemical compositions are shown in Table 1; the physical characteristics in Table 2. X-ray diffraction revealed that neither glass presents crystalline structures. When subjected to the modified Chapelle test, glass particles showed pozzolanic activity with 562.13 and $655.20 \mathrm{mg}$ of $\mathrm{Ca}(\mathrm{OH})_{2}$ per gram of colorless and amber glass, respectively (23). Results from the electrical conductivity test - adopting the method proposed by Luxan et al. (24) - suggest moderate pozzolanic activity for both glass types. According to the strength activity index testing of ASTM C311-7 (25), the glasses are

TABLE 2. Physical properties of glass and cementitious materials.

\begin{tabular}{lccc}
\hline Item & Colorless & Amber & Cement \\
\hline Specific Mass $\left(\mathrm{g} / \mathrm{cm}^{3}\right)$ & 2.60 & 2.54 & 2.81 \\
Average size $(\mu \mathrm{m})$ & 8.93 & 10.61 & 38.0 \\
Specific surface $\mathrm{BJH}\left(\mathrm{m}^{2} / \mathrm{kg}\right)$ & 4.265 & 4.918 & 5.250 \\
\hline
\end{tabular}

TABLE 1. Chemical components of glass and cementitious materials (\%)

\begin{tabular}{lccccccccccccc}
\hline Material & $\mathbf{S i O}_{\mathbf{2}}$ & $\mathrm{Al}_{2} \mathbf{O}_{\mathbf{3}}$ & $\mathbf{C a O}$ & $\mathbf{F e}_{2} \mathbf{O}_{\mathbf{3}}$ & $\mathbf{M g O}$ & $\mathbf{S O}_{3}$ & $\mathbf{N a}_{\mathbf{2}} \mathbf{O}$ & $\mathbf{K}_{\mathbf{2}} \mathbf{O}$ & $\mathbf{C r}_{2} \mathbf{O}_{3}$ & $\mathbf{S r O}$ & $\mathbf{T i O}_{2}$ & $\begin{array}{c}\text { Insoluble } \\
\text { residue }\end{array}$ & $\begin{array}{c}\text { Loss on } \\
\text { ignition }\end{array}$ \\
\hline Colorless & 73.93 & 0.25 & 9.18 & 0.92 & 3.75 & 0.23 & 9.18 & 0.02 & 0.53 & 0.19 & $<0.01^{*}$ & 92.72 & 0.22 \\
Amber & 72.95 & 0.82 & 9.28 & 0.66 & 3.58 & 0.25 & 9.99 & 0.02 & $<0.01^{*}$ & 0.04 & 0.2 & 94.39 & 0.37 \\
Cement & 24.59 & 7.19 & 56.47 & 2.8 & 2.43 & 2.60 & 0.03 & 0.82 & $<0.01^{*}$ & $<0.01^{*}$ & $<0.01^{*}$ & 1.0 & 3.50 \\
\hline
\end{tabular}

*Data below the instrument detection limit. 
pozzolanic, so it is impossible to evaluate the influence of glass composition on the pozzolanic activity.

To evaluate the influence of glass microparticles on the properties of cementitious compounds, cement and mortar-with 0,10 , and $20 \%$ of the cement replaced by colorless and amber glass microparticles - were analyzed. For the compounds, a cement with a low additive content $(5 \%)$ and high tricalcium silicate content, to favor the pozzolanic reactions (Tables 1 and 2), was used. As a fine aggregate, treated natural siliceous sand (specific mass of $2650 \mathrm{~kg} / \mathrm{m}^{3}$ ) with grain sizes of $1.2,0.6$, 0.3 , and 0.15 in equal proportions was used. After mixing, the materials were molded under mechanical vibration and the specimens were cured at $25^{\circ} \mathrm{C}$ in saturated surroundings for time periods ranging from 7 to 90 days.

Based on the degree of substitution and the type of glass, the following nomenclature was employed for the mortars: control ( $0 \%$ replacement), colorless $-10 \%$, colorless $-20 \%$, amber $-10 \%$, and amber $-20 \%$. The values of the water / cement ratio or binder (w/b) were 0.4 or 0.5 , depending on the test, since the standards of each test required a different ratio.

Setting time, semi-adiabatic calorimetry, and soundness/expansion tests were performed using cement paste samples with and without waste glass. Workability (on a flow table), compressive strength, flexural strength, elastic modulus, and thermography tests were performed on mortar specimens.

The influence of adding glass microparticles at the interval between the mixing process on the loss of plasticity of the mixture was evaluated by testing the setting time using a Vicat Needle (26). The soundness test was utilized for evaluating the influence of glass particles on the dimensional stability of compounds with respect to the possible occurrence of undesirable volumetric expansion after hardening. As expansion can manifest months or even years after the manufacture of cement compounds, the Le Chatelier needles method $(27,28)$ was employed for this test. Three test specimens were manufactured for each type of studied cement paste (with and without waste glass) at their normal consistency.

Hydration heat was qualitatively and indirectly analyzed by a semi-adiabatic calorimetry test. Water/ cement and water/cement + glass pastes at a ratio of 0.4 were prepared and analyzed (standard laboratory procedure). The test was carried out using a Grace AdiaCal (Sn 1272434) system sealed in a box equipped with four outlets and four thermocouples for recording sample temperatures.

The flow table test evaluated the workability and homogeneity of mortars with and without waste glass (29). The analyzed mortar composition was 1 part binder (cement + cement or glass microparticles) to 3 parts sand, with a w/b ratio of 0.5 . Two tests were performed on each type of mortar.
Tests to evaluate the hardened form properties were performed on specimens made from mortar whose composition was similar to that used in the flow table test. The apparent porosity of the cementitious compounds was evaluated by an oxygen permeability test-based on the recommendation of RILEM TC 116- PCD (30). Compressive strength tests were carried out at 7, 28, and 90 days on $50 \times 100 \mathrm{~mm}$ cylindrical test specimens in a TC-PS 003 press with a load application of $0.5 \mathrm{MPa} / \mathrm{s}(31)$. Three samples per compound were tested. Bending tests were performed at 28 days in an Emic universal testing machine-model DL30000N-with a load application speed of $0.8 \mathrm{MPa} / \mathrm{s}$ (32). Two tests were performed on each compound.

The elastic modulus was determined by longitudinal forced resonant frequency (33) using an Erudite MKII at a voltage of $0.10 \mathrm{~V}$. Frequencies varied from 13000 to $25000 \mathrm{~Hz}$ based on a step of $10.00 \mathrm{~Hz}$. In total, 2 specimens - ten measurements of each sample-were measured.

The emissivity and thermal diffusivity of the mortars were evaluated by infrared thermography. An FLIR ThermaCam (model P640, with temperature range from $-40^{\circ} \mathrm{C}$ to $500^{\circ} \mathrm{C}$ and measurement reading accuracy of $\pm 2 \%$ ) infrared camera was used. In order to define the study parameters, a reflected temperature of $50^{\circ} \mathrm{C}$, air temperature of $20^{\circ} \mathrm{C}$, and relative humidity of $50 \%$, were adopted. The thermal emissivity was estimated using the known emissivity technique: a material of known emissivity is used (insulating tape) and with the infrared camera, the emissivity value is varied until the temperature measured in the material is in equilibrium with the value measured in the insulating tape. To evaluate the diffusivity, the samples were placed in an insulated box and subjected to a constant heat flow generated by a $127 \mathrm{~V}, 500 \mathrm{~W}$ halogen lamp. The distance between the lamp and sample was $0.80 \mathrm{~m}$ and the ambient temperature was recorded by a thermo-hygrometer clock (Minipa MT-241). Images were analyzed with Quick Report software, and graphics were made in Microsoft Excel. From the data obtained, we calculated the thermal diffusivity of the mortars using the one-dimensional heat conduction model for transient semi-infinite solids, with a boundary condition of the second kind, considering a heat flow $\left(q{ }^{\prime \prime}\right)$ constant on the surface - Equation [1]

$T(x, t)-T_{i}=\frac{2 q^{\prime \prime}{ }_{0} \sqrt{\frac{\alpha t}{\pi}}}{K} e\left[-\frac{x^{2}}{4 \alpha t}\right]-\frac{q^{\prime \prime}{ }_{0}}{K} \operatorname{erfc}\left[\frac{x}{2 \sqrt{\alpha t}}\right]$

where $T(x, t)$ is the temperature $\left({ }^{\circ} \mathrm{C}\right), T_{i}$ is the surface temperature $\left({ }^{\circ} \mathrm{C}\right)$ identifiable at the initial time, $q "{ }_{0}$ is the constant heat flow $\left(\mathrm{W} / \mathrm{m}^{2}\right)$ applied to the 
identifiable surface, $\alpha$ is the solid thermal diffusivity $\left(\mathrm{m}^{2} / \mathrm{s}\right), t$ is time (s), $K$ is the thermal conductivity of the solid $(\mathrm{W} / \mathrm{m} \cdot \mathrm{K}), x$ is the position $(\mathrm{m})$, and $\operatorname{erfc}(w)$ is the complementary error function-which is the Gauss error function. Thermal conductivity was determined using the hot plate method.

\section{RESULTS AND DISCUSSION}

To study setting and expandability times, the normal cement paste consistency (Table 3) was first determined. The data revealed that the 10 and 20\% partial cement replacement by glass microparticles slightly affected the amount of water required to obtain a normal cement paste consistency. This might have occurred because glasses have specific surfaces that are close to those of cement.

Table 4 shows the setting time test results for cement pastes with and without glass microparticles. The use of waste glass had a small influence on the initial and final setting times. This could be related to the similar specific surface of the particles. The nature and level of substitution do not appear to influence the setting times. This situation is similar to others described in the literature $(17,18,34)$, where it is reported that the use of recycled glass as a cement substitute (up to a level of $25 \%$ ) does not significantly affect the initial setting time. However, the final setting time is slightly affected by both types of glass. This is probably due to the lower $\mathrm{SO}_{3}$ content in the compounds with glass.

Results of the soundness tests (according to the Le Chatelier method) revealed that the needles did not open in any of the examined cement pastes (18). According to the literature, free lime and magnesium

TABLE 3. Characteristics of the normal cement paste consistency

\begin{tabular}{lcc}
\hline Cement paste & w/b & Penetration depth $(\mathbf{m m})$ \\
\hline Control & 0.33 & 6.0 \\
$10 \%$ colorless & 0.35 & 6.8 \\
$20 \%$ colorless & 0.35 & 6.9 \\
$10 \%$ amber & 0.35 & 5.6 \\
$20 \%$ amber & 0.35 & 6.4 \\
\hline
\end{tabular}

TABLE 4. Setting time test results

\begin{tabular}{lccc}
\hline Cement paste & Initial (min) & Final (min) & Setting time (min) \\
\hline Control & 120 & 250 & 130 \\
$10 \%$ colorless & 120 & 235 & 115 \\
$20 \%$ colorless & 115 & 235 & 120 \\
$10 \%$ amber & 125 & 245 & 120 \\
$20 \%$ amber & 120 & 240 & 120 \\
\hline
\end{tabular}

oxide present in waste glass can become hydrated after the cement has set and cause unwanted expansion (35). However, this did not occur-probably because these compounds were present at low levels.

The semi-adiabatic calorimetry test results for samples containing 10 and $20 \%$ waste glass are shown in Figures 1 and 2, respectively. In both figures, the blue line represents the empty compartment, while the green line represents the control paste. In Figure 1, each sample exhibits an incubation period of approximately $2 \mathrm{~h}$. After this period, it was observed that the temperature of the samples increased at an accelerated rate-likely due to the formation of calcium hydroxide and hydrated calcium silicates. In the compounds with glass, that temperature rise was noted to be slower. The maximum temperature was reached in all three samples by approximately $7.5 \mathrm{~h}$. The highest temperature $\left(43.8^{\circ} \mathrm{C}\right)$ was observed in the control cement paste. The paste with $10 \%$ replacement by colorless glass microparticles reached a peak temperature of $41.9^{\circ} \mathrm{C}$. That with $10 \%$ replacement by amber glass reached $41^{\circ} \mathrm{C}$.

In Figure 2, samples also show an incubation period of approximately $2 \mathrm{~h}$. The use of glass particles - especially amber - delayed the formation of hydrated silicates and calcium hydroxide. For the control cement paste, the peak temperature was $41^{\circ} \mathrm{C}$. The cement paste with $20 \%$ replacement by colorless glass microparticles reached a peak temperature of $39^{\circ} \mathrm{C}$. That with $20 \%$ replacement by amber glass reached $37^{\circ} \mathrm{C}$. It could be noted that the highest level of substitution delayed the hydration reaction without affecting the post-acceleration time. Both factors are typical of cements with pozzolanic additions.

The results reveal that the use of glass microparticles -10 or $20 \%$, colorless or amber - affected the heat of hydration of the cement. However, the higher the glass microparticle content, the less heat of hydration generated. This was expected due to the smaller amounts of clinker employed, resulting in lower levels of heat released during hydration reactions. Different from the observations of Kamali and Ghahremaninezhad (17), the use of $20 \%$ glass delayed the hydration of the cement paste, reinforcing the point of view that glass microparticles with the current granulometry do not act as an inert material.

The workability test (Figure 3) revealed that the samples containing glass microparticles had low workability and that the use of colorless microparticles promoted less spreading than amber microparticles.

The level of substitution seemed not to influence workability, since the differences found were within the error range of the measurements. The same trend can be seen in the literature $(15,19)$. The effect of glass on the workability could be related 
Influence of soda-lime waste glass microparticles on workability and thermal properties of portland cement compounds $\bullet 5$

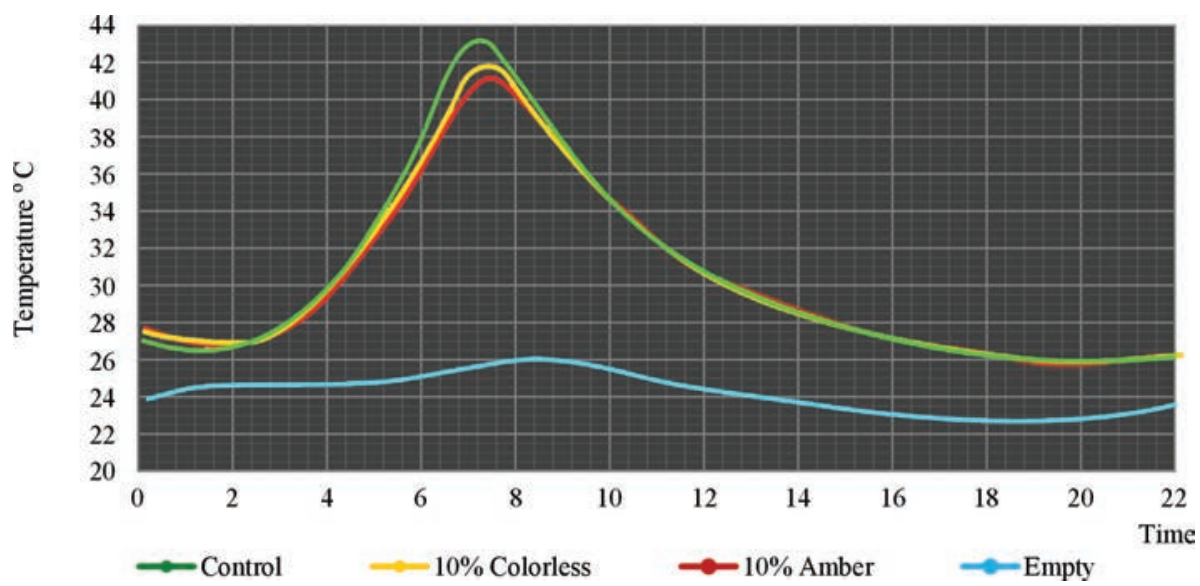

FIGURE. 1. Results of differential scanning calorimetry tests with power compensation on cement pastes with and without $10 \%$ cement replacement by colorless/amber glass microparticles

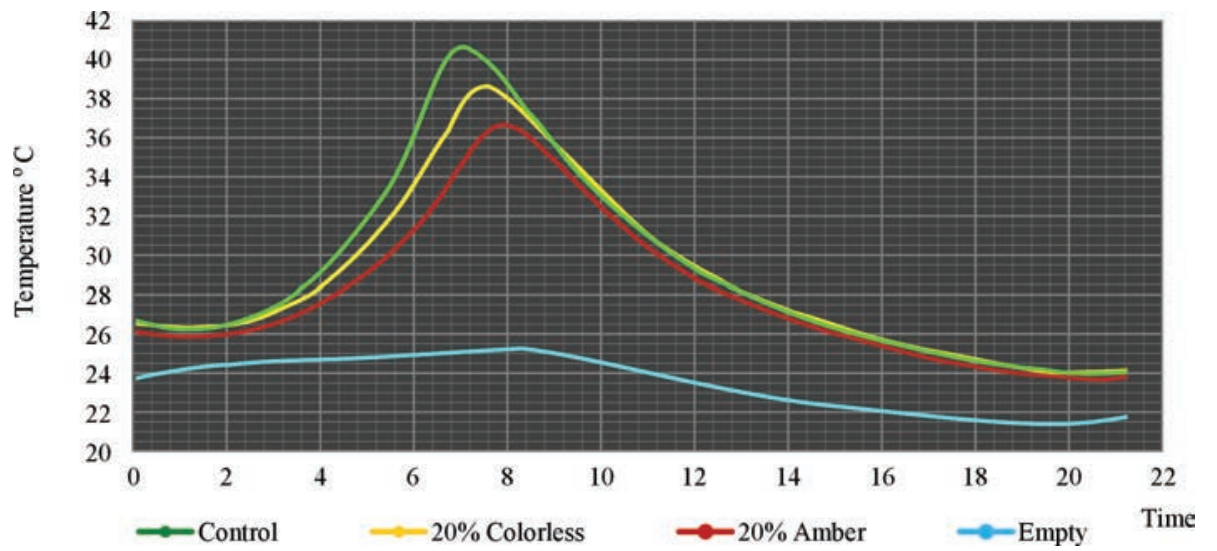

FIGURE. 2. Results of differential scanning calorimetry tests with power compensation on cement pastes with and without $20 \%$ cement replacement by colorless/amber glass microparticles.

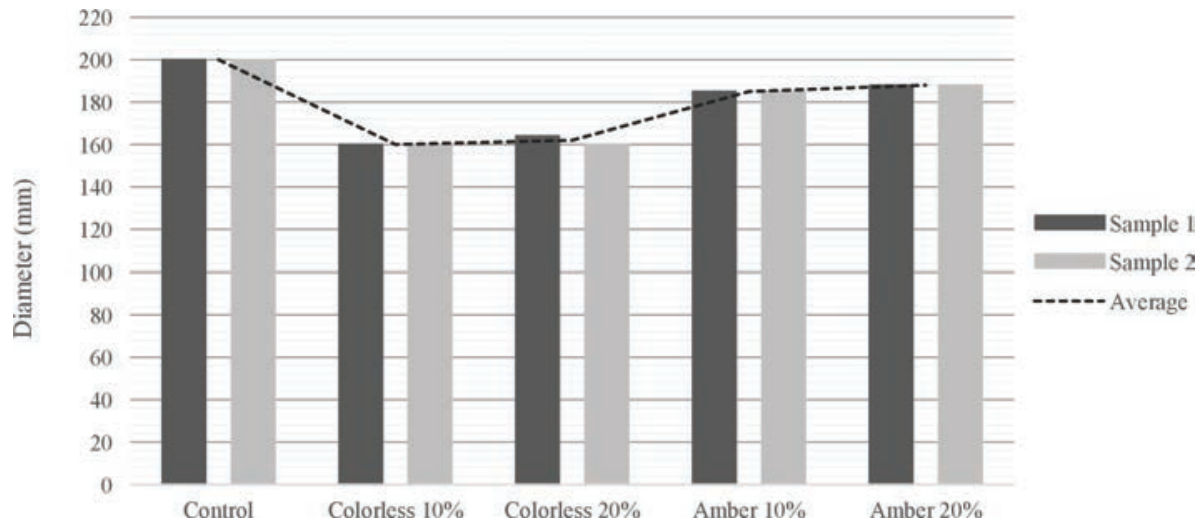

FIGURE. 3. Workability - spreading diameter.

to the predominantly elongated microparticles-- - a morphology that increases the friction between particles. This morphology is due to the process of obtaining the microparticles by grinding / milling.
In the case of amber glass, the processed surfaces were smoother-possibly because the particles are harder than those of colorless glass (higher aluminum oxide content). This would reduce the 
possibility of the particles interlocking and require less water to achieve the same workability.

The results indicate that the use of glass microparticles contributed to reduced permeability by 12 and $28 \%$ for 10 and $20 \%$ colorless glass, respectively; and 27 and $37 \%$ for 10 and $20 \%$ amber glass, respectively. The permeability improvement was probably due to the occurrence of a pozzolanic reaction and filler effect that would promote refinement, increase the tortuosity of the network, and decrease connectivity. The greatest reduction associated with amber glass would be related to its smoother surface that would better accommodate the particles.

Figure 4 shows the mean scores and standard deviations obtained in the composite compressive strength tests with and without the use of glass microparticles. All mixtures showed a monotonic increase in compressive strength with curing time. At each stage analyzed, the addition of $10 \%$ colorless or amber glass was associated with a slight increase in the compressive mechanical strength of the samples. The $20 \%$ glass substitutions had a lower influence on compression strength and tended to decrease the strength of the compound at 7 and 28 days of curing. However, at 90 days, the values were similar to those of the compound without glass $(16,18,20)$. These results differ from those observed by Islama, Rahmanb, and Kazia (21); and indicate that the alumina content in the glasses was insufficient to promote microcracking due to the formation of ettringite at late stages. This would decrease the compressive strength (19) of the material. The results show that the reduction in permeability is not directly associated to increase in compressive strength. This could be related to the fact that the glass microparticles might also be acting as filler, the void filling mechanism having less effect on mechanical strength and this property depends strongly on the slow pozzolanic reaction. The increase in mechanical strength associated with $10 \%$ glass content would be related, in the early stages, only to the filling of voids by microparticles and, at 90 days, to the formation of calcium silicates due to the pozzolanic reaction. In the case of $20 \%$ glass content, the low initial resistance would be related to a smaller quantity of cement available for the hydration reaction and would be compensated by the pozzolanic reaction in more advanced stages.

Figure 5 shows the flexural strength test results performed at 28 days of curing (mean and range of measurements).

Considering the accuracy of the measurements, the results show that the presence of glass microparticles had almost no effect on the flexural strengthlikely due to the pozzolanic reaction kinetics and filler effect $(15,18)$.

Figure 6 shows the elastic modulus results obtained by longitudinal resonant frequency, considering the average and standard deviations of 10 measurements for each mortar type. The elastic modulus - around 45-50 GPa at 28 and 90 dayswas practically unaffected by the use of glass microparticles and was very close to the reference results, regardless of the nature and amount of substitution. This means that the sample's microcracking was not affected by the use of microparticles and / or that neither decreased calcium hydroxide content nor increased hydrated calcium silicates in the pozzolanic reaction altered the modulus. Put differently, the modulus is not sensitive to the calcium hydroxide content. This result differs from that obtained by Calmon et al. (19) in a study involving waste windshield glass particles smaller than $75 \mathrm{~mm}$. These differences are related to the presence or absence of microcracks in the mixture.

The emissivity value measured in all samples was 0.95 . This means that using glass microparticles does not influence the mortar's ability to emit energy by radiation. This value is close to that reported by Incropera and DeWitt (36) for cementitious compounds and glass.

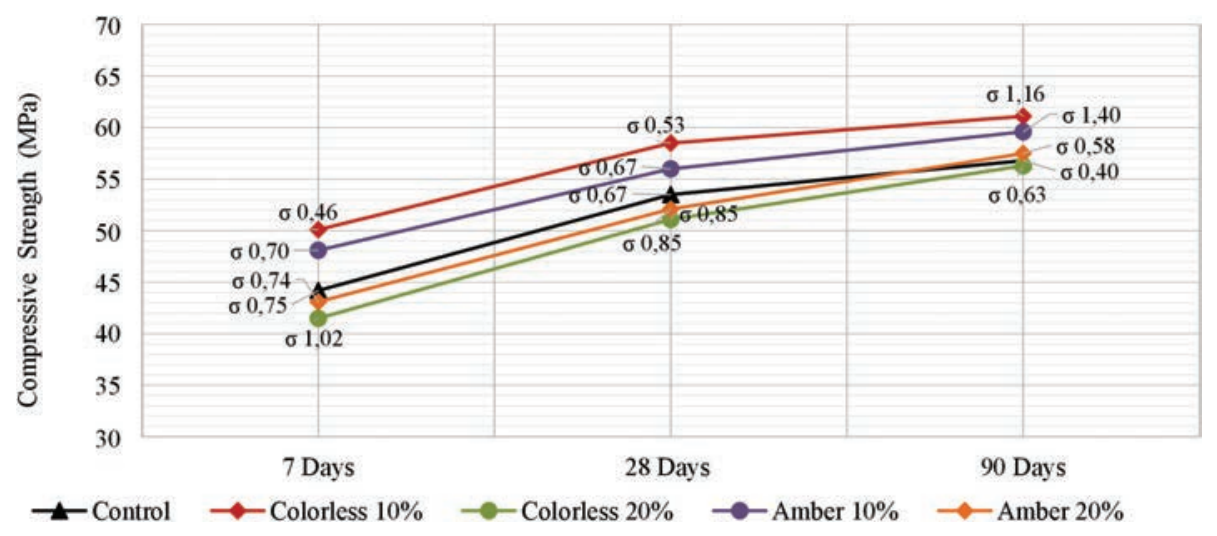

FIGURE. 4. Mortar compressive strength results ( $\mathrm{s}=$ standard deviations). 


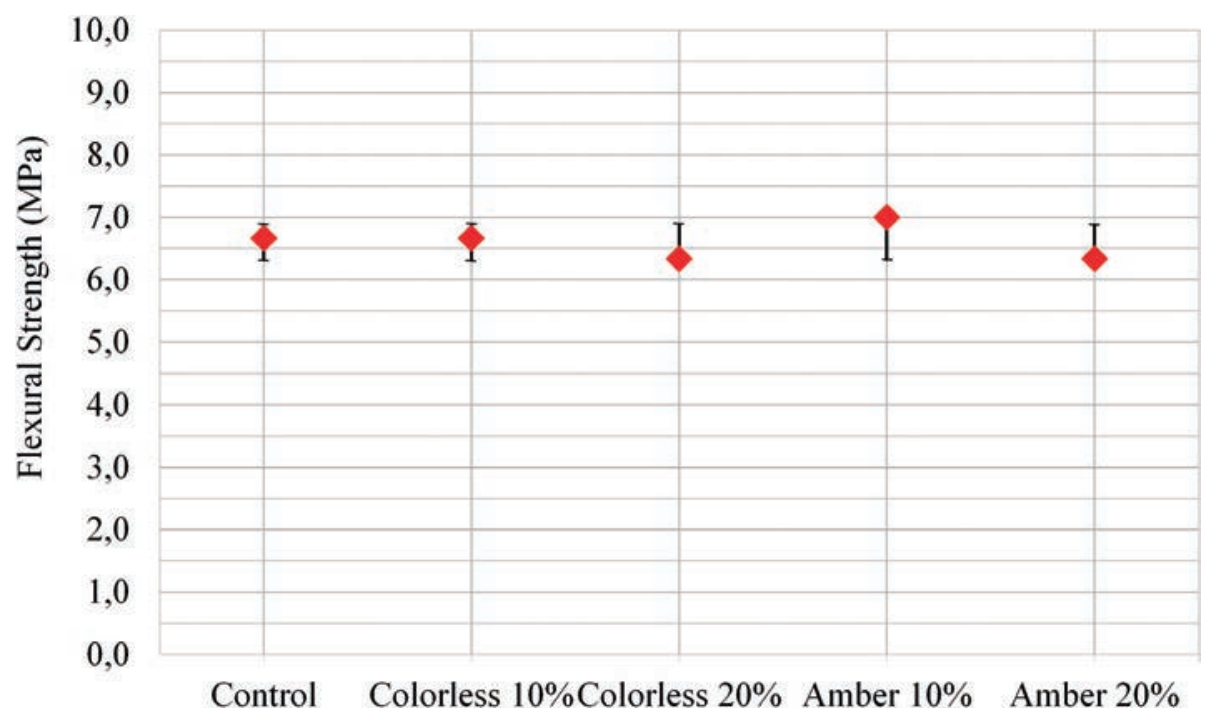

Figure. 5. Mortar flexural strength test results at 28 days.

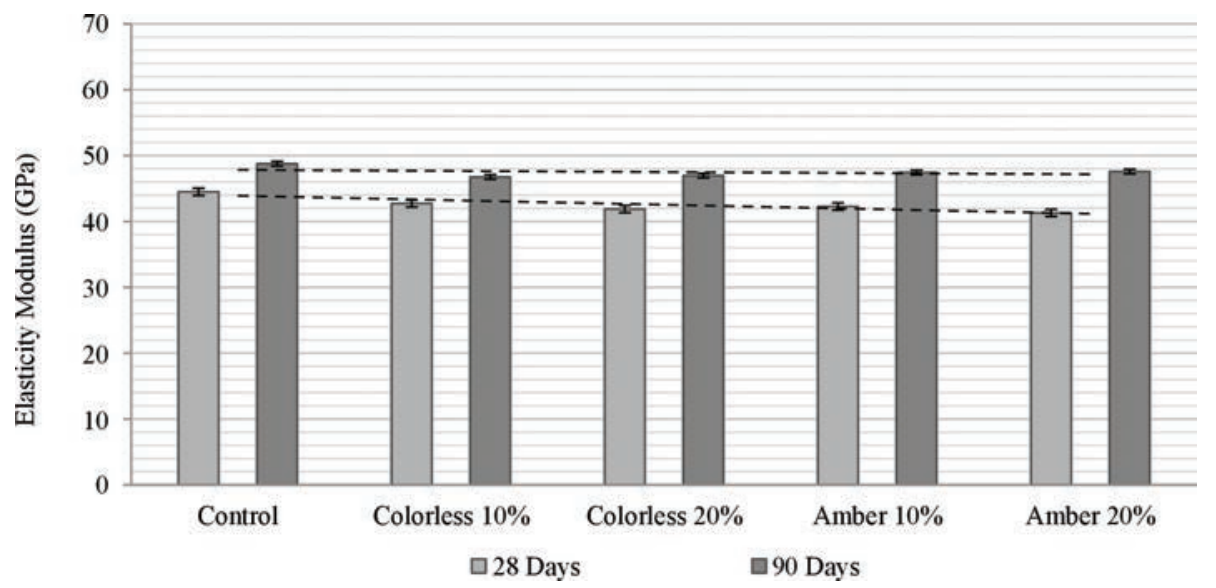

FIGURE. 6. Elastic modulus results obtained by longitudinal resonant frequency of mortars at 28 and 90 days.

The thermal conductivity of samples without glass was $1.23 \pm 0.09 \mathrm{~W} / \mathrm{m} \cdot \mathrm{K}$. For samples with colorless glass it was $1.02+0.10$ and $0.95+0.08 \mathrm{~W} / \mathrm{m} \cdot \mathrm{K}$, for 10 and $20 \%$ replacement, respectively. For amber glass, it was $1.07 \pm 0.07$ and $0.99 \pm 0.07 \mathrm{~W} / \mathrm{m} \cdot \mathrm{K}$ for 10 and 20\% replacement, respectively. The lower porosity of the samples with glass did not promote an increase in the thermal conductivity as expected. This may be related to the pore size of the matrix $(0.5-4 \mu \mathrm{m})$ and / or the increased silica content due to the substitution. Either case is more efficient for thermal conductivity reduction than permeability, since they each improve the radiation absorption that contributes to reduced conductivity (37).

Figure 7 shows the thermal diffusivity values of mortars with and without glass microparticles. Diffusivities were calculated from Equation 1, whereas the temperature profiles were determined by thermography.
The results show that the thermal diffusivity of the control sample was higher than that of the samples containing glass. This means that the addition of glass slowed the diffusion of heat, which could have contributed to maintaining the internal temperature in the same way that lower-diffusivity materials retard the transfer of external temperature variations to the interiors of buildings. This probably occurred because the thermal diffusivity varies directly with thermal conductivity and inversely with the specific mass, and the samples with glass had lower thermal conductivity and lower porosity than the control sample.

\section{CONCLUSIONS}

The results indicated that replacement of 10 and $20 \%$ of cement by colorless and amber glass microparticles did not significantly affect the 


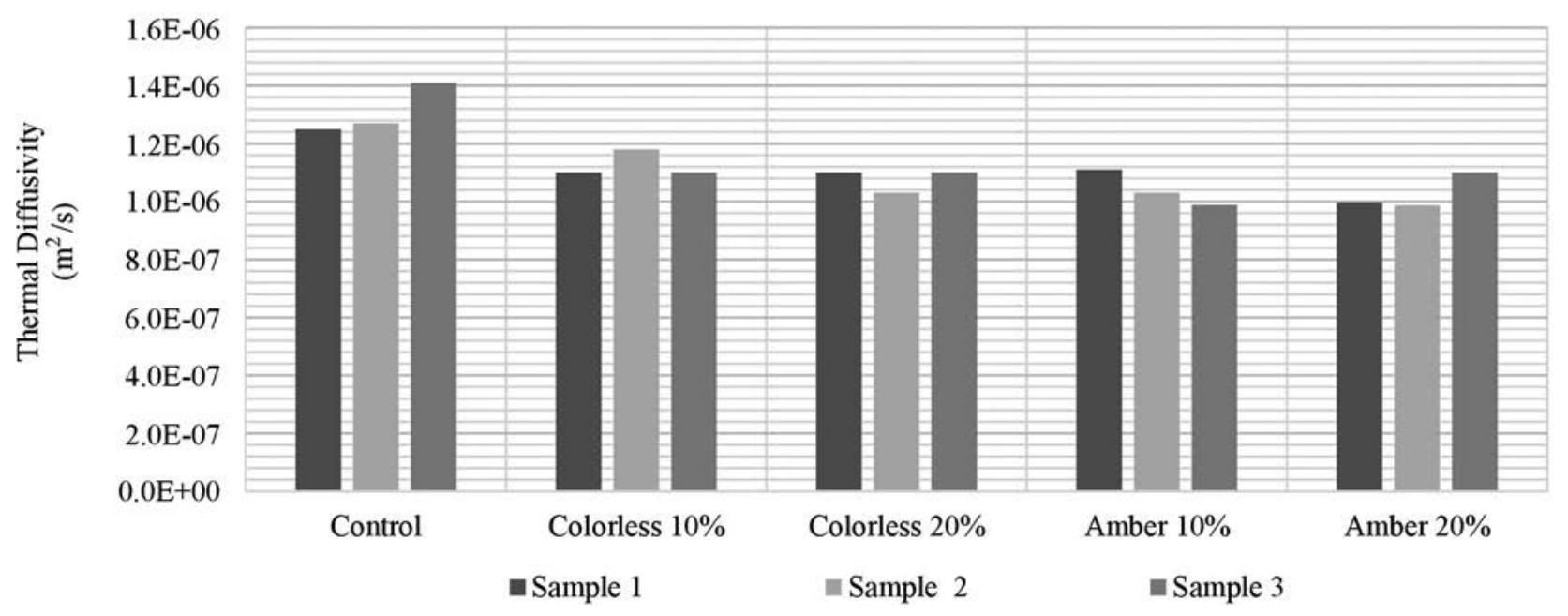

FIgure. 7. Thermal diffusivity values of the mortars.

setting times. However, the final setting time was marginally affected by each type of glass. The results revealed that the use of glass microparticles - colorless or amber-reduced the heat of hydration of the cement. However, the reduction was greater when $20 \%$ amber glass microparticles were used. The use of glass microparticles seemed not to influence the expansion of cement pastes as measured by the Le Chatelier method but decreased the flowability. The replacement of 10 and $20 \%$ of cement by colorless and amber glass microparticles did not influence the elastic modulus, nor the flexural strength. The $10 \%$ substitution caused a slight increase $(\sim 6 \%)$ in the compressive strength at all stages studied. The $20 \%$ substitution caused a slight decrease in the compressive strength; however, this negative effect disappeared after 90 days of curing. No significant influence on mechanical performance due to chemical composition - that is the color of the glass - was detected. However, the content and the chemical composition did appear to influence the workability and permeability of the cementitious compounds. Regarding heat of hydration, this influence was observed at $20 \%$ substitution, and more significantly for amber glass. The results indicate that glass microparticles did not influence the mortar's ability to emit energy through radiation but did affect the thermal conductivity and thermal diffusivity.

The results showed that 10 or $20 \%$ amber glass substitution was sufficient to reduce the heat of hydration, permeability, and thermal diffusivity of the cementitious compounds without significantly changing the mechanical properties after 90 days of curing. However, the use of glass - especially colorless-compromised the workability of the compound; probably due to the roughness and morphology of the particles.

\section{ACKNOWLEDGEMENTS}

This work was supported by the Coordination for the Improvement of Higher Education Personnel (CAPES), the Research Support Foundation of the State of Minas Gerais (FAPEMIG), and the National Council for Scientific and Technological Development (CNPq).

\section{REFERENCES}

1. Abravidro (2018) Associação Brasileira de Distribuidores e Processadores de Vidros Planos. Panorama Abravido, 2018. Marita Martins. Brasília, (2018). Available in: https:// pdf.magtab.com/leitor/136/edicao/18702.

2. Cempre. (2017) Compromisso empresarial para reciclagem. Available in: www.cempre.org.br.

3. Torres-Carrasco, M.; Puertas, F. (2015) Waste glass in the geopolymer preparation. Mechanical and microstructural characterisation. J. Clean. Prod. 90, 397-408. https://doi. org/10.1016/j.jclepro.2014.11.074

4. Arulrajah, A. Kua, T.A.; Horpibulsuk, S.; Phetchuay, C.; Suksiripattanapong, C.; Dud, Y. J. (2016) Strength and microstructure evaluation of recycled glass-fly ash geopolymer as low-carbon masonry units. Construc. Build. Mat. 114, 400-406. https://doi.org/10.1016/j.conbuildmat.2016.03.123.

5. Cyr, M.; Idir, R.; Poinot, T. (2012) Properties of inorganic polymer (geopolymer) mortars made of glass cullet. J. Mater. Sci. 47, 2782-2797. https://doi.org/10.1007/ s10853-011-6107-2.

6. Jani, Y.; Hogland, W. (2014) Waste glass in the production of cement and concrete: a review. J. Environ. Chem. Eng. 2, 1767-1775. https://doi.org/10.1016/j.jece.2014.03.016.

7. Tariq, S.; Scott, A.; Mackechnie, J. (2016). Controlling Fresh Properties of Self-Compacting Concrete Containing Waste Glass Powder and its Influence on Strength and Permeability. In $4^{\text {th }}$ International Conference on Sustainable Construction Materials and Technologies. August 2016. Las Vegas, USA.

8. Du, H.; Tan, K.H. (2017) Properties of high volume glass powder concrete. Cem. Concr. Comp. 75, 22-29. https://doi. org/10.1016/j.cemconcomp.2016.10.010.

9. Omrana, A.; Harbec, D.; Tagnit-Hamoua, A; Gagne, R. (2017) Production of roller-compacted concrete using glass powder: Field study. Construc. Build. Mat. 133, 450-458. https://doi.org/10.1016/j.conbuildmat.2016.12.099. 
10. Omrana, A F, Morina, ED, Harbec, D, Tagnit-Hamoua, A (2017) Long-term performance of glass-powder concrete in large-scale field applications. Construc. Build. Mat. 135, 43-58. https://doi.org/10.1016/j.conbuildmat.2016.12.218.

11. Mohajerani, A.J.; Cheung, T.H.H.; Kurmus, H.; Arulrajah, A.; Horpibulsuk, S. (2017) Practical recycling applications of crushed waste glass in construction materials: a review. Construc. Build. Mat. 156, 443-467. https://doi. org/10.1016/j.conbuildmat.2017.09.005

12. Dumitru, I.; Song, T.; Caprar, V.; Brooks, P.; Moss, J. (2010) Incorporation of recycled glass for durable concrete. In $2^{\text {nd }}$ International Conference on Sustainable Construction Materials and Technologies, June 2010. Ancona, Italy.

13. Serpa, D.; Silva, A.; Brito, J.; Pontes, J.; Soares, D. (2013). ASR of mortars containing glass. Constr. Build. Mater. 47, 489-495. https://doi.org/10.1016/j.conbuildmat.2013. 05.058 .

14. Du, H.; Tan, K. (2013) Use of waste glass as sand in mortar: Part II - Alkali-silica reaction and mitigation methods. Cem. Concr. Comp. 35(1), 118-126. https://doi.org/10.1016/j. cemconcomp.2012.08.029.

15. Kamali, M.; Ghahremaninezhad, A. (2015) Effect of glass powders on the mechanical and durability properties of cementitious materials. Construc. Build. Mat. 98, 407-416. https://doi.org/10.1016/j.conbuildmat.2015.06.010.

16. Lee, H; Hanif A; Usmand, M; Sim, J; Oh, H. (2018) Performance evaluation of concrete incorporating glass powder and glass sludge wastes as supplementary cementing material. J. Clean. Prod. 170, 683-693. https://doi. org/10.1016/j.jclepro.2017.09.133.

17. Kamali, M.; Ghahremaninezhad, A. (2016) An investigation into the hydration and microstructure of cement pastes modified with glass powders. Construc. Build. Mat. 112, 915-924. https://doi.org/10.1016/j.conbuildmat.2016.02.085.

18. Aliabdo, A.A.; Elmoaty, A.; Aboshama, A.Y. (2016) Utilization of waste glass powder in the production of cement and concrete. Construc. Build. Mat. 124, 866-877. https://doi.org/10.1016/j.conbuildmat.2016.08.016

19. Calmon, J.; Sauer, A.; Vieira, G.; Teixeira, J. (2014) Effects of windshield waste glass on the properties of structural repair mortars. Cem. Concr. Comp. 53, 88-96. https://doi. org/10.1016/j.cemconcomp.2014.04.008

20. Rodier, L.; Savastano, S. (2018) Use of glass powder residue for the elaboration of eco-efficient cementitious materials. J. Clean. Prod. 184, 333-341. https://doi.org/10.1016/j. jclepro.2018.02.269.

21. Islama, G.M.S.; Rahmanb, M.H.; Kazia, N. (2017) Waste glass powder as partial replacement of cement for sustainable concrete practice. J. Sustain. Built Environ. 37-44. https://doi.org/10.1016/j.ijsbe.2016.10.005.

22. Bignozzia, M.C.; Saccania, A.; Barbieri, L.; Lancellotti, I. (2015) Glass waste as supplementary cementing materials: The effects of glass chemical composition. Cem. Concr.
Compos. 55, 45-52. https://doi.org/10.1016/j.cemconcomp. 2014.07.020

23. Raverdy, M.; Brivot, F.; Paillère, A.; Dron, R.; (1980) Appréciation de l'activité pouzzolanique des constituants secondaires. In $7^{\text {th }}$ International Congress on the Chemistry of Cement. June/July 1980. Paris, France.

24. Luxán, M.; Madruga, F.; Saavedra, J. (1989) Rapid evaluation of pozzolanic activity of natural products by conductivity measurement. Cem. Concr. Res. 19, 63-68. https:// doi.org/10.1016/0008-8846(89)90066-5

25. ASTM C311-07 (2007) Standard test methods for sampling and testing fly ash or natural pozzolans for use in Portland cement concrete. Book of Standards. West Conshohocken, PA.

26. ASTM C191-99 (2001) Standard test method for time of setting of hydraulic cement by Vicat Needle. Book of Standards. West Conshohocken, PA.

27. ASTM C1567-08 (2008) Standard Test Method for Determining the Potential Alkali-Silica Reactivity of Combinations of Cementitious Materials and Aggregate. Accelerated Mortar-Bar Method. Book of Standards. West Conshohocken PA.

28. EN 196-3 (2016) Methods of Testing Cement - Part 3: Determination of Setting Times and Soundness. European Committee for Standardization (CEN), Brussels.

29. ASTM C230-99 (1999) Standard specification for flow table for use in tests of hydraulic cement. West Conshohocken, PA.

30. RILEM TC116-PCD (1999) Tests for gas permeability of concrete. Materials and Structures. RILEM Technical Committees.

31. ASTM C39M-15 (2015) Standard test method for compressive strength of cylindrical concrete specimens. West Conshohocken, PA.

32. ASTM C78M-15 (2015) Standard test method for flexural strength of concrete (using simple beam with third-point loading). West Conshohocken, PA.

33. ASTM C215-97 (1997) Standard test method for fundamental transverse, longitudinal, and torsional frequencies of concrete specimens. West Conshohocken, PA.

34. Chikhalikar, S.; Tande, S. (2012) An experimental investigation on characteristic properties of fibre reinforced concrete containing waste glass powder as pozzolana. In $37^{\text {th }}$ Conference on Our World in Concrete \& Structures, August 2012. Singapore, Asia.

35. Mehta, P.; Monteiro, P. (2014) Concrete: Microstructure, properties, and materials. McGraw-Hill. New York.

36. Incropera, F.P.; De Witt, D.P.; Bergman, T.L.; Arianne, S.L. (2017) Incropera's Principles of Heat and Mass Transfer. Wiley \& Sons.

37. Feng, J-; Chen, D.; Ni, W; Yang, S. Hu, Z (2010). Study of Ir absorption properties of fumed silica-opacifier composites. J. Non. Cryst. Solids. 480-483. https://doi. org/10.1016/j.jnoncrysol.2009.12.015. 